\title{
THE MARKAN NARRATIVE'S USE OF THE OLD GREEK TEXT OF JEREMIAH TO EXPLAIN ISRAEL'S OBDURACY
}

\author{
Larry Perkins
}

\begin{abstract}
Summary
A close reading of the Septuagint (LXX) translation of Jeremiah in conjunction with a careful examination of Markan contexts where Jeremiah materials occur reveals that Jeremiah's prophetic message influences the Markan portrayal of Jesus' words and deeds, especially to explain Israel's obduracy. By examining specific contexts in Mark's narrative (chs. 8, 11, 13, 14) where potential intertextual linkages with the Greek version of Jeremiah's prophecy occur I demonstrate the potential contribution of the Greek version of Jeremiah's material to our understanding of Mark's purpose. His use of Jeremiah material seems to focus almost exclusively on aspects of opposition that Jesus experienced. The general theme of Israel's obduracy, illustrated by the temple cleansing incident, the parable of the tenant farmers, and the prophecy about the destruction of Jerusalem and the temple seems to provide the thread that the Markan author finds useful to link with Jeremiah's message.
\end{abstract}

\section{Introduction}

Considerable attention has been given to the function of Isaiah $^{1}$ materials in the Markan narrative. Relatively little consideration, in contrast, has been paid to the potential influence of the LXX text of Jeremiah on this gospel's story. A glance at the Index of Quotations

1 Rikki Watts, Isaiah's New Exodus in Mark (Grand Rapids, MI: Baker Book House, 2000). 
and Allusions in the Nestle-Aland $27^{2}$ lists two quotations and five allusions in Mark's Gospel. Given this limited, explicit textual relationship, it is not surprising that little attention has been paid to the use and possible influence of Jeremiah's material in Mark's narrative. A close reading of the LXX translation of Jeremiah in conjunction with careful examination of Markan contexts where Jeremiah materials occur reveals a different perspective. Jeremiah's prophetic message influences the Markan portrayal of Jesus' words and deeds, especially to explain Israel's obduracy.

It is time for a reappraisal. ${ }^{3}$ We have an edited text of the LXX of Jeremiah, done by Joseph Ziegler (1976). ${ }^{4}$ A New English Translation of the Septuagint was published in 2007 giving updated, general access to these texts. ${ }^{5}$ The understanding of Mark's Gospel as narrative and the implications of this for its interpretation have received remarkable and fruitful attention during the past twenty years - and this shows no signs of abating. With the publication of the Dead Sea Scrolls we perceive more clearly the significance of intertextuality, orality, and the use of the Old Testament materials in Second Temple Judaism.

Mark $^{6}$ intended his audience to hear echoes and allusions in Jesus' words and deeds to the message and actions of Jeremiah the prophet. In this he accords with the interest in Jeremiah materials within Second Temple Judaism. Ben Sira, for example, links the destruction of Jerusalem to the persecution of Jeremiah. The Babylonians

Set fire to the chosen city of the sanctuary, and made her streets desolate by the hand of Jeremiah, for they afflicted him yet he had been consecrated...to pluck up and afflict and destroy, and likewise to build and to plant (49:6-7).

2 Nestle-Aland, Novum Testamentum Graece post Eberhard et Erwin Nestle editione vicesima septima revisa (Germany: Deutsche Bibelgesellschaft, 1993).

3 Considerable work on the function of Jeremiah materials in Matthew's Gospel exists. Consider Michael Knowles, Jeremiah in Matthew's Gospel: The Rejected Prophet Motif in Matthean Redaction (JSNTSS 68; Sheffield: Sheffield Academic Press, 1993).

4 Joseph Ziegler, ed., Septuaginta Vetus Testamentum Graecum XV: Ieremias, Baruch, Threni, Epistula Ieremiae (Göttingen: Vandenhoeck and Ruprecht, 1976). All LXX quotations from Jeremiah will be taken from this edition.

5 Albert Piertersma and Benjamin Wright, ed., A New English Translation of the Septuagint (Oxford: Oxford University Press, 2007).

6 I use 'Mark' to refer to the person who wrote the second Gospel. 
Josephus sees himself as a new Jeremiah. ${ }^{7}$ He reports that Jeremiah not only prophesied about the destruction of Jerusalem in his day, but also about its destruction at the hands of the Romans.

This prophet also announced the misfortunes that were to come upon the city, and left behind writings concerning the recent capture of our city, as well as the capture of Babylon. ${ }^{8}$

Knowles suggests as well that Josephus' description of the prophet Jeshua ben Ananias links him with Jeremiah. Jeshua, a contemporary of Josephus, had prophesied the destruction of Jerusalem for seven years, shouting throughout the city 'Woe to Jerusalem'. 9 Thus for Mark, writing in the latter half of the First Century, as well as for Jesus himself, incorporating Jeremiah typology into his narrative would fit well within the Jewish first-century context. ${ }^{10}$

For Mark the hostility of the Israelites towards Jeremiah and his message becomes a way to explain opposition to Jesus. Key passages ${ }^{11}$ in Mark's narrative where quotation (as marked in Nestle-Aland 27) or allusion to Jeremiah ${ }^{12}$ may give specific edge to Jesus' comments include:

7 David Daube, 'Typology in Josephus', JJS 31 (1980): 18-36.

8 Josephus, Ant. 10.79 [Marcus, LCL].

9 Michael Knowles, Jeremiah, 253-54. Josephus, B.J. 6.300-309 [Thackeray, LCL].

10 In 2 Macc. 15:11-19 Judas Maccabees receives a vision of Onias, the displaced high priest, speaking to him, along with Jeremiah, the prophet. Jeremiah is noted as 'the lover of his brethren' and one who offered many prayers for his people and the holy city. He gives to Judas a golden sword. 'Take the golden sword as a gift from God and with it shatter our enemies'. This is one example of how Jeremiah continued to serve as an example and inspiration within Judaism.

11 Mark 11:12-14, 20-25; 12:2-4 and 14:58; 15:29 are not noted in Nestle-Aland as allusions. Mark 1:17 is linked with Jer. 16:16 in Nestle-Aland. They also suggest that the parable of the seeds and soils (Mark 4:1-20) and its interpretation may also be related to a passage such as Jer. 4:3 "This is what the Lord says to the men of Judah and to Jerusalem: "Break up your unplowed ground and do not sow among thorns.", Jer. 12:13 is also referenced. Cf. James Edwards, The Gospel according to Mark (Grand Rapids, MI: Eerdmans, 2002): 128; R. T. France, The Gospel of Mark: A Commentary on the Greek Text (Grand Rapids, MI: Eerdmans, 2002): 191; Robert Gundry, Mark: A Commentary on His Apology for the Cross (Grand Rapids, MI: Eerdmans, 1993): 194. While it is difficult to argue for a direct and intentional allusion by Jesus to Jeremiah's prophecy in particular, we should note the linkage between the analogy of sowing seed, thorns and obduracy.

12 Distinguishing between Old Testament quotation and allusion in the New Testament is notoriously difficult. For the purposes of this paper a quotation is marked

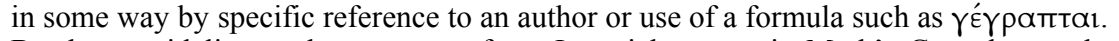
By these guidelines only one quote from Jeremiah occurs in Mark's Gospel, namely 11:17. All others references to Jeremiah material would be allusions, i.e. material that 
Jeremiah

Like Jeremiah, Jesus in Mark's narrative through word and deed pronounced oracles of judgement against the Temple and Jerusalem and their religious leadership. Moreover, the rejection and condemnation that Jesus experienced is similar to that which Jeremiah received from his contemporaries. The sentence of death for Jeremiah was sought actively by the priests and the prophets. Jeremiah escaped death (Jer. 26:24), but a contemporary prophet, Uriah, was not so fortunate (Jer. 26:20-23). Even though Jeremiah as a character never appears explicitly in the Markan narrative, ${ }^{13}$ there are sufficient examples of intertextual influence to show that Mark related Jesus to Jeremiah's message, action and treatment and invited his audience to understand and interpret the opposition to Jesus' message and action in the light of what Jeremiah the prophet experienced.

Our method will be rather straightforward. Because of space limitations, we will consider four key elements in Mark's story - the obduracy motif, the pronouncements against the temple and the barren fig tree episode, the parable of the tenant farmers, and Jesus' discourse about the destruction of Jerusalem - and seek to discern whether significant lexical and thematic parallels occur between Mark's narrative and LXX Jeremiah. ${ }^{14}$ In addition, content analysis will be

shows some lexical/syntactical connection with LXX Jeremiah and stimulates consideration of that text for the interpretation of that segment of Mark's narrative. An allusion is a literary device that potentially activates two texts such that the evoked text influences the interpretation of the alluding text. Cf. Richard Hays, Echoes of Scripture in the Letters of Paul (New Haven, CT: Yale University Press, 1989): 25-33.

13 Mark 8:28 notes contemporary opinions about Jesus ('Some say John the Baptist; others say Elijah, and still others, one of the prophets'), but Matthew (16:14) writes 'Some say John the Baptist; others say Elijah; and still others, Jeremiah or one of the prophets', explicitly mentioning Jeremiah. Matthew may be making explicit what is implicit in Mark, thereby emphasising the relationship between Jesus and Jeremiah.

14 Establishing intertextuality is methodologically complex. Note the discussion by Richard Hays, Echoes, 21-33. He acknowledges that 'varying levels of certainty' will attend specific instances and proposes seven criteria 'for testing claims about the 
employed in cases where lexical parallels may not be explicit. If such instances of intertextuality can be demonstrated, then this will lead us to propose that Mark deliberately sought to draw the biblically literate person in his audience to reflect upon Jeremiah's story as a type of Jesus and of reactions to him. ${ }^{15}$ We use the LXX version of the Old Testament as our basis of comparison because the Markan author normally used it as the source of most of his explicit quotations. This would lead us to assume that he had access to this version in some form and regarded it as a legitimate expression of the Jewish sacred materials. There is significant difference between LXX translation of Jeremiah and the Masoretic Text. However, in the contexts we consider, differences between the Greek and Hebrew texts of Jeremiah do not materially affect the kinds of intertextual influence being proposed. The verbal parallels become more apparent when the Greek texts are compared.

\section{Mark 8:17-18}

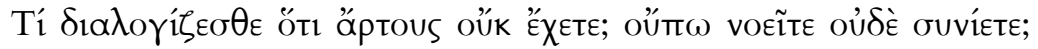

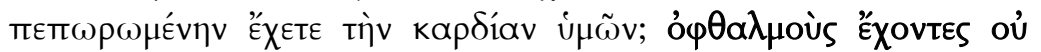

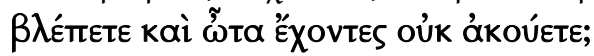

Why are you talking about having no bread? Do you still not perceive or understand? Are your hearts hardened? Do you have eyes and fail to see? Do you have ears, and fail to hear? ${ }^{16}$

\section{Jeremiah 5:21, 23}

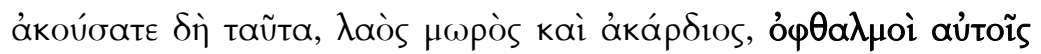

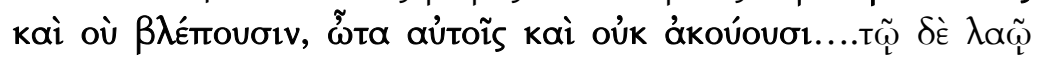

presence and meaning of scriptural echoes in Paul'. These include availability, volume, recurrence, thematic coherence, historical plausibility, history of interpretation and satisfaction. I would suggest that the proposed relationship between the Markan narrative and Jeremiah meets all of these criteria. Cf. L. Perkins, 'Kingdom, Messianic Authority and the Re-Constituting of God's People-Tracing the Function of Exodus Materials in Mark's Narrative' in Biblical Interpretation in Early Christian Gospels: The Gospel of Mark (Edinburgh: T \& T Clark, 2006): 100-115.

15 Whether these proposed connections with Jeremiah's prophecy and life were emphasized by Jesus himself or were part of the tradition received by Mark or something Mark developed are significant questions, but space prevents their treatment.

16 English translations of the New Testament and Hebrew Old Testament are taken from the Common Bible: New Revised Standard Version (Nashville: Thomas Nelson Publishers, 1989). Abbreviated as NRSV. 


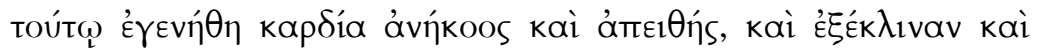
àmí $\lambda \theta$ ooav.

Do you hear these things, $O$ foolish and heartless people; eyes they have and do not see, ears they have and do not hear...but this people had a noncompliant and disobedient heart; they have turned aside and gone away. ${ }^{17}$

Obduracy is a very significant theme in Mark's Gospel. Whether it is the Jewish leaders or his most intimate followers, Jesus accuses them of obduracy (hardness of heart, spiritual blindness and deafness). The parable of the soils (4:1-20) forms the classic context where the Markan author expounds his theology of obduracy, using the language of Isaiah. Those 'on the outside' of Jesus' circle 'may indeed look, but not perceive, and may indeed listen, but not understand; so that they may not turn again and be forgiven'. ${ }^{18}$

Mark 8:18 presents a similar situation. ${ }^{19}$ We find no explicit quotation formula, but the language Jesus uses parallels Jeremiah 5:2120, with perhaps some reference to Isaiah 6:9, 10. The word order in Mark's narrative, the parallelism between ó $\varphi \theta \alpha \lambda \mu$ ós / $\beta \lambda \varepsilon^{\prime} \pi \omega$ and oư / ákoú $\omega$, and the reference in the Markan context to misunderstanding, if linked with Jeremiah's accusations of 'a foolish and senseless people', support this conclusion. Jeremiah also describes their

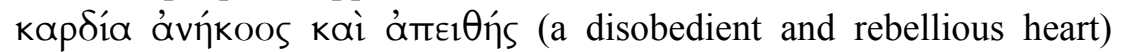

17 A New English Translation of the Septuagint, 886.

18 Mark 4:12 (NRSV). Most commentators consider Jesus to be quoting from Isa. 6:9-

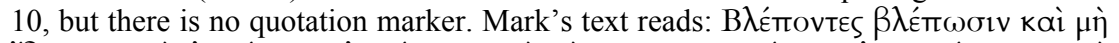

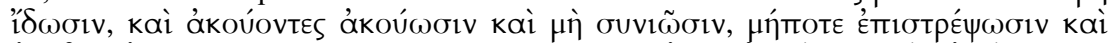

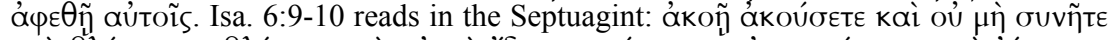

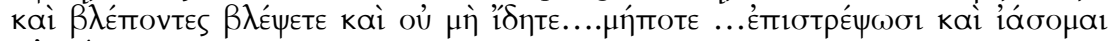
aútoús. C. Evans, To See and Not Perceive: Isaiah 6:9-10 in Early Jewish and Christian Interpretation (Sheffield: Sheffield Academic Press, 1989): 91-92 suggests that 'Mark's paraphrase is an abbreviation of the Isaianic text'. Consensus seems to be that Mark is paraphrasing Isaiah, but in ways that are similar to the Targum. Notice, however, the order (seeing... hearing) reflects that of Jeremiah, not Isaiah both in Mark 4:12 and 8:17-18.

19 M. Beavis, Mark's Audience: The Literary and Social Setting of Mark 4:11-12. (JSNTSS 33; Sheffield: Sheffield Academic Press, 1989) argues (pp. 90-91, 150-53) that 'contrary to majority opinion...the OT verse behind $8: 17-18$ is the third option, Isaiah 6:10a, the part of the quotation left out in Mark 4:12'. Yet the textual affinities seem to lie more closely with LXX Jeremiah.

20 C. Evans, To See and Not Perceive, 91-92 states that 'the references to the hardened heart, unseeing eyes, and unhearing ears recall many of the obduracy passages (Isa. 6:9-10; Jer. 5:21, 23; Deut. 29:3; Ezek. 12:2), with perhaps Isa. 6:9-10 and Jer. 5:21, 23 closest'. 
which corresponds to Jesus' reference to the disciples'

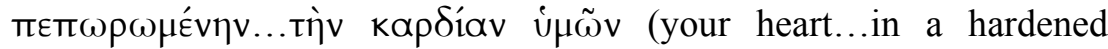
condition) in 8:17. Just as Jeremiah warned Israel that their "prophets [are] prophesying falsely and the priests rule as the prophets direct' (Jer. 5:31), so Jesus warned his disciples about the leaven of the Pharisees and Herod (Mark 8:14).

Mark used $\pi \omega ́ \rho \omega \sigma \iota s$ (hardness) terminology to describe this obduracy faced by Jesus. This terminology is not paralleled in the LXX or the other Synoptics. ${ }^{21}$ In fact in the New Testament only Paul and John use this terminology. ${ }^{22}$ In 6:52 the Markan narrator concludes the story of the feeding of the five thousand by saying the twelve did not understand about the loaves 'but their heart was in a hardened condition'. ${ }^{23}$ The loaves mentioned in 8:14-21 generate another use of this verb (8:17) 'Do you still not perceive or understand? Are your hearts in a hardened condition?' 24 In both contexts the obduracy of the twelve reflects their unwillingness or inability to accept what these actions reveal about Jesus. Mark considers obduracy to be the fundamental cause of the disciples' conflict with Jesus, their desertion, and their deficient faith response.

The obduracy of the Jewish leaders was similar but different. In Mark 3:5 Jesus is 'grieved at the hardness of their heart'. ${ }^{25}$ They rejected Jesus' claim to be messiah altogether because his teachings and actions challenged the fundamental elements of Judaism-Sabbath, dietary regulations, and rules of holy cleanliness. He became an antimessiah in their minds. So it is not a surprise to find them conspiring to destroy him—and succeeding.

21 In 10:5 and 16:14 (the longer ending to Mark) $\sigma k \lambda \eta p o k \alpha \rho \delta i ́ \alpha$ occurs. Matthew reads this at 19:8.

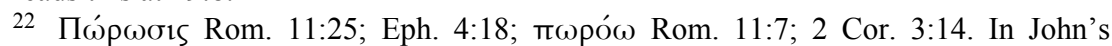
Gospel the verb occurs at 12:40 in an explicit quotation from Isa. 6:10, but its wording does not match the Septuagint text. Cf. C. Evans, 'Obduracy and the Lord's Servant: Some Observations on the Use of the Old Testament in the Fourth Gospel' in Early Jewish and Christian Exegesis: Studies in Memory of William Hugh Brownlee, ed. Craig Evans and William Stinespring (Atlanta, GA: Scholars Press, 1987): 221-36.

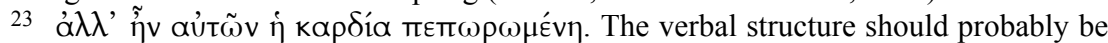
considered periphrastic and the translation probably should reflect a stative sense. The participle could be middle or passive.

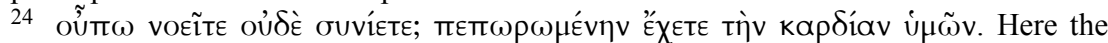
adverbial participle is also perfect middle or passive in form, literally 'In a hardened condition do you have your heart?' Fronting the participle puts it in the emphatic position.

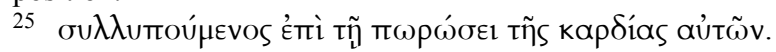


In Jeremiah 5-8 the theme of obduracy among the people and leaders of Judaea emerges in vigorous, diverse forms. Using content analysis, we can discern at least three aspects to this theme in Jeremiah:

1. The general characterisation that there was no desire to change and respond to God.

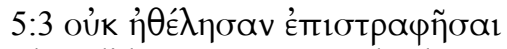

They did not want to turn back!

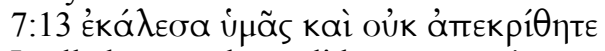

I called you and you did not answer!

2. Their actions were consistently viewed as senseless, rebellious, unjust - the people loved it.

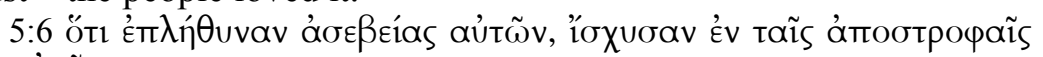
aủTก̃v.

Because they have multiplied their impieties, they prevailed in their digressions.

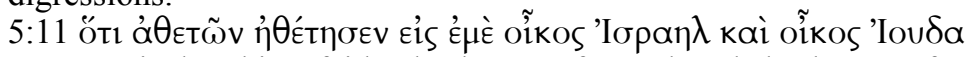

Because in breaking faith, the house of Israel and the house of Judah broke faith with me.

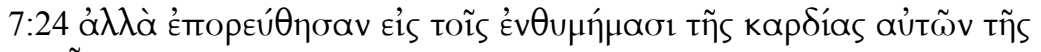
Kakñs

But they walked by the notions of their evil heart.

3. Jeremiah described the people and their leaders as deaf, senseless and stiff-necked.

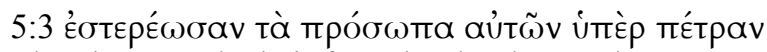

They have made their faces harder than rock.

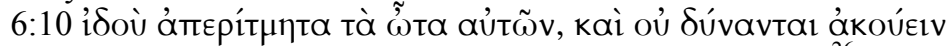

Behold, their ears are uncircumcized and they cannot hear! ${ }^{26}$

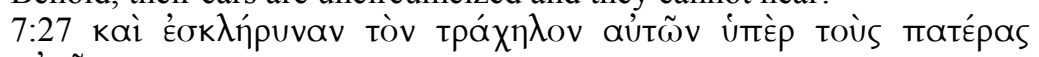

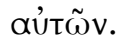

And they stiffened their neck worse than their fathers.

Jeremiah's description of Israel's obduracy reflected God's view that they had rejected His commands, broken His covenant, and acted in rebellious ways that were far worse than anything their ancestors had committed. Yet, the people and their leaders did not agree with Jeremiah's analysis. So Jeremiah made his proclamations, warned the people about their obduracy, but there was no change, only deeper and fiercer hostility.

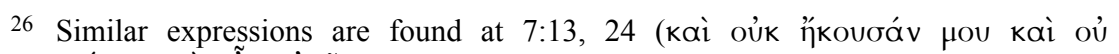

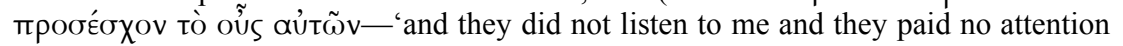
with their ear' [my translation]) and 27. 
Several specific verbal connections exist between the obduracy theme in Mark's narrative and Jeremiah's oracles, as Mark 8:17-18 and Jeremiah 5:21, 23 demonstrate. As well, many conceptual similarities are evident, such as the refusal to listen, the 'stiff neck', the lack of repentance, the claim to righteousness, the mistreatment of widows, and a heart condition that is evil. All of these ideas in Jeremiah can be paralleled in Mark's story, particularly as Jesus criticized the Jewish leaders on various occasions. While other Old Testament prophets presented similar criticisms, the allusion in Mark 8:17-18 to Jeremiah $5: 21,23$, would, in my opinion, focus our attention particularly upon Jeremiah's presentation of these ideas as Mark's primary ideological backdrop.

\section{Mark 11:17-18}

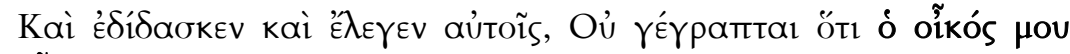

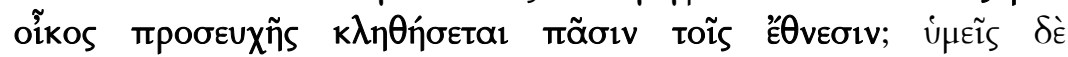

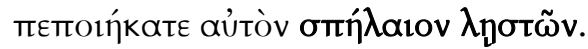

And he [Jesus] was teaching and saying, 'Is it not written, "My house shall be called a house of prayer for all the nations"? ${ }^{27}$ But you have made it a "den of robbers".'

\section{Jeremiah 7:10-11}

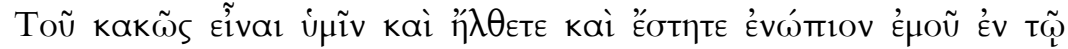

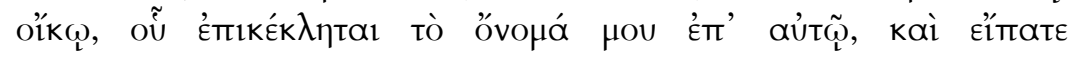

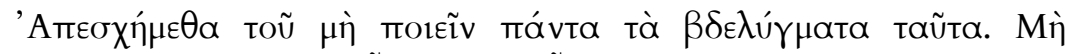

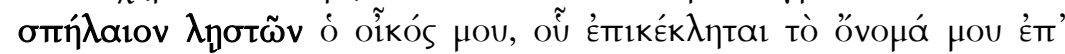

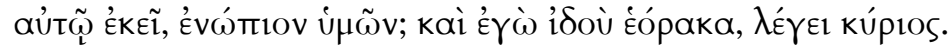

'So that it $\left({ }^{28}\right)$ be ill for you and if you came and stood before me in the house where my name has been called on it, and you said, "We have kept away from doing all these abominations"-surely my house, there where my name has been called on it, has not become a den of robbers before you? And I, behold, I have seen it,' says the Lord.

In Mark 11-13 the temple dominates the narrative. The day after he entered Jerusalem, Jesus went directly to the temple concourse. The

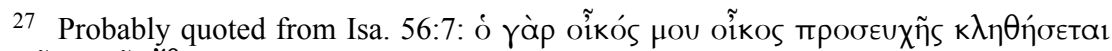

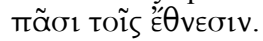

28 Jeremiah lists these ills as murder, adultery, theft, false oaths and pursuing foreign gods, a summary of the commands of the Decalogue that Israel has rejected. 
narrative summarizes Jesus' actions and proclamation, criticising the temple hierarchy and their management of Israel's most holy place.

The author sandwiches the account of Jesus' temple action within the story of the cursing of the barren fig tree (Mark 11:12-25), reinforcing Jesus' evaluation of Israel's use of the temple and precipitating his attack on money-changers, animal sellers, and those carrying 'merchandise' through the temple courtyard (Mark 11:1516). ${ }^{29}$ His words quoted from Isaiah and Jeremiah should also be seen in the same vein, as announcing the destruction of the temple, the symbol of hope for Jewish restoration. ${ }^{30}$

Mark 12-13 reveals what the full implications of this destruction will be, if the ruling, religious elite reject Jesus' message. The narrator's report in Mark 11:18, that the religious leaders continued their conspiracy to destroy Jesus, does not create any optimism that they will repent. The following day Peter observed the fig tree in a withered state and Jesus explains that faith, prayer and forgiveness will still be possible even if there is no temple. For Jesus the temple was no longer essential to God's purposes and vision of the restored Israel. ${ }^{31}$

The probable connections between Jesus' actions and teachings in this section of the Markan narrative and Jeremiah 7-8 are rather extensive. ${ }^{32}$ First, Jeremiah 7 contains Jeremiah's oracle of judgement against Jerusalem and the temple. He accused the Israelites and their leaders of disregard for covenant responsibilities - they 'steal, murder,

29 Mark 11:15-16. Exactly what Jesus was restricting in the third matter is disputed. C. Evans, Mark 8:27-16:20 (WBC 34B; Nashville, TN: Thomas Nelson, 2001): 173, draws attention to Josephus' comment that 'No vessel whatever might be carried into the temple' (A. Ap. 2.8.106). He also notes Chilton's suggestion that 'Jesus' action here should be interpreted in the light of Zech. 14:20-21 in which the prophet foretells the day when traders will no longer be present in the temple'.

30 The significance of Jesus' pronouncement and action in the temple precinct is disputed. The point here, however, is what the Markan narrator was wanting to convey through this segment of his narrative. E. P. Sanders, Jesus and Judaism (Philadelphia, PA: Fortress Press, 1985): 75 concludes 'that Jesus publicly predicted or threatened the destruction of the temple,...' His action is 'symbolic of its destruction'.

31 C. Evans, Mark 8:27-16:20, 188-89. W. R. Telford, The Barren Temple and the Withered Tree (Sheffield, England: JSOT Press, 1980), 115-18, argues that 'This mountain' refers to the temple mount and is further comment on the destruction that was coming to the temple. Consider also the discussion on this passage by Sharon Dowd, Prayer, Power and the Problem of Suffering: Mark 11:22-25 in the Context of Markan Theology (Atlanta, GA: Scholars Press, 1988).

32 Consider as well the discussion of these parallels in C. Evans, 'Jesus and the "Cave of Robbers": Towards a Jewish Context for the Temple Action' in Jesus and His Contemporaries Comparative Studies (Leiden: E. J. Brill, 1995): 362-65. 
commit adultery, swear falsely, make offerings to Baal and go after other gods that you have not known, and then come and stand before me in this house,...' (Jer. 7:9-10). The disconnect between moral behaviour and covenant responsibility led God to challenge their assumption that 'we are safe'. Jeremiah accused them of converting the temple into 'a den of robbers' (Jer. 7:11). ${ }^{33}$ God counselled them to 'Go now to my place that was in Shiloh, where I made my name dwell at first and see what I did to it for the wickedness of my people Israel' (Jer. 7:12). Jeremiah referred to the destruction of the tent of meeting by the Philistines (1 Sam. 4:10-11), which was God's response to the sinful, priestly conduct of Eli's sons. The implication of this oracle is clear. The destruction of Jerusalem and the temple was imminent, unless the Israelites repented (Jer. 7:5-7).

The context for the Markan Jesus is similar as he went into the temple and through his actions challenged the priests' management of 'my' house. His quotation from Jeremiah 7:11 drew attention to a prior prophetic warning to Israel not to place naïve reliance on the presence of the temple for its security when Israel no longer fulfilled its covenant responsibilities. There is no doubt about the connotation of Jeremiah's use of $\sigma \pi \hat{\eta} \lambda \lambda_{10 v} \lambda \eta \emptyset \sigma \tau \tilde{\omega} v$ as Jeremiah 7:9-10 indicates. The activities of Israel ${ }^{34}$ in stealing, murdering and perverting justice meant that when they come to worship God in the temple they hijack its intended use and convert it into a 'den of bandits'. In Jesus' day everyone in Israel knew what had happened to Solomon's temple and why. The violence and injustice permeating Israelite society, in Jeremiah's day eventually brought God's judgement and Jesus warns of a similar outcome for his contemporaries.

Mark's narrative does not immediately make clear why Jesus condemned the temple cultus. Presumably his reasons would be similar

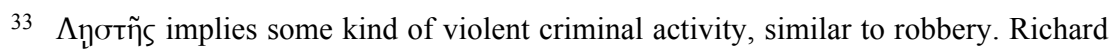
Horsley with John S. Hanson, Bandits, Prophets and Messiahs (Harrisburg, PA: Trinity Press International, 1985): 52-87, has made a strong case that 'social banditry' was prevalent during the first part of the First Century and grew in intensity as Roman taxation became so oppressive that the poor could not survive. C. K. Barrett, 'The House of Prayer and the Den of Thieves' in Jesus und Paulus. Festschrift für Werner Georg Kümmel zum 70. Geburtstag (Göttingen: Vandenhoeck \& Ruprecht, 1985): 16, concludes that the connotation of 'nationalist rebel' dominates, because of the usage of this term in Josephus' writings. The accusation then would be: 'You have made the temple a nationalist stronghold'. The same phrase occurs in a variant LXX text at Jer. 12:9.

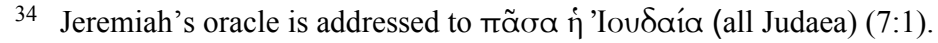


in some way to those enumerated by Jeremiah, because he makes direct reference to his oracle. Regardless of the reasons for Jesus' actions and words, the parallel with Jeremiah's prior oracle, its place of delivery, and its implication for the audience's understanding of Jesus, must be taken seriously, because Jesus himself in the narrative makes this connection. 35

The fig tree ${ }^{36}$ frame for Jesus' temple action in Mark 11:17-18 provides a second connection with Jeremiah's situation. In Jeremiah 8:13 the prophet says:

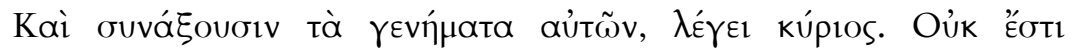

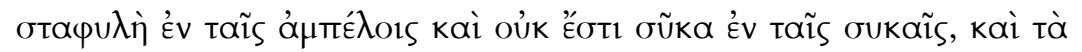

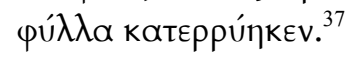

The Greek translation tells how the invaders sent by God will come to take the crops, but there is no produce - a different interpretation than found in the Masoretic text. The idea is somewhat similar, however, in that whether it is Yahweh or Yahweh's agent, when they come to take the produce, there is nothing there. Expectations of harvest are dashed. There are no grapes or figs - the leaves of the fig trees have withered. The Jeremiah context bemoans that 'summer has ended; harvest passed, and we were not saved' (Jer. 8:20). Jesus similarly in his temple actions was symbolising its judgement. ${ }^{38}$ If the Jewish religious elite and people rejected him, the temple and its cultus would be destroyed.

A third element connecting Jeremiah's oracle and Jesus' temple pronouncement is the response of the religious elite to his prophetic action, namely they kept seeking for a way to destroy him (Mark 11:18). This theme is introduced earlier in Mark's narrative (3:6) and

35 As D. Juel, Messiah and Temple, 133, and others caution, we must not necessarily assume that the use of material from the Old Testament necessarily means that the narrator wants that entire context to be the basis for understanding this quotation or allusion. 'Atomistic exegesis, quoting a verse without regard for its context, is a practice familiar to Christian and Jewish exegetes. But in this case, the setting of the verse in Jeremiah cannot be accidental.'

36 In the Old Testament prophets Israel frequently is symbolized by a fig tree (Hos. 9:10; Jer. 8:13; 24; 29:17; Joel 1:7; Mic. 7:1-6; Ezek. 17:24). When the fig tree is destroyed, it marks judgement (Hos. 2:12; Isa. 34:4).

37 'and they will gather their produce, says the Lord; there are no grapes on the vines and there are no figs on the fig trees; even the leaves have fallen off.'

38 R. Stein, 130 concludes that '...the cleansing of the temple..., in Mark...is understood as an act of judgment. Jesus has rejected Israel. She has been weighed in the balances and found wanting...Mark interprets the cleansing by means of the cursing.' 
there is a parallel with Jeremiah's experience. In Jeremiah 11:18-19, 21 his fellow townsmen from Anathoth were plotting his death, because he prophesied the destruction of Jerusalem and the temple. When Jeremiah repeats a prophecy about the destruction of the temple and city during the reign of Jehoiakim, son of Josiah (Jer. 33[26]:1-9), he is seized by the priests, false prophets and the people. A trial is hastily convened and Jeremiah is preserved from execution only through the intervention of some leaders. However, in the narrative mention is made of 'Uriah son of Shemaiah from Kiriath Jearim... who... prophesied the same things against this city and this land as Jeremiah did'. Jehoiakim seized Uriah in Egypt and brought him back to Jerusalem for execution (Jer. 33[26]:20-23). Prophesying the divine destruction of Jerusalem and its temple was widely viewed in the Sixth Century BC as a traitorous act, not a divinely mandated action.

What Jeremiah and Jesus experience in response to their temple oracles is very similar. In Jeremiah 7:6 the prophet warned the Judaeans, 'do not shed innocent blood in this place' ( $\alpha \tilde{i} \mu \alpha$ a $\theta \tilde{\omega} O v \mu \grave{\eta}$

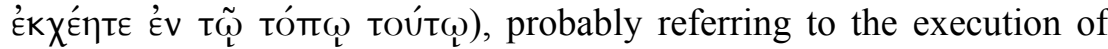
Uriah, the prophet. During his trial (33[26]:15) Jeremiah tells the court that he has done nothing wrong and if they execute him, then 'you are bringing innocent blood upon yourselves, and upon this city' (aî $\mu \alpha$

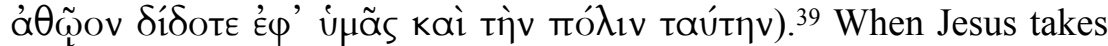
the cup at his last Passover, he tells his followers that 'this is my blood

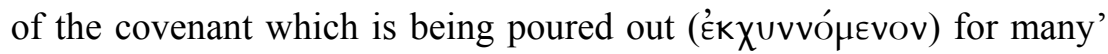
(Mark 14:24)..$^{40}$ Jesus is alluding to the violent death he will experience in a few hours. Jeremiah and Jesus have the same message and received the same response. ${ }^{41}$

39 Other references to 'innocent blood' occur in Jer. 2:34; 19:4; 22:3, 17.

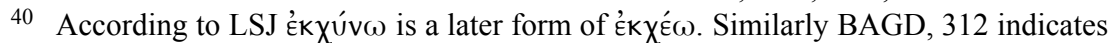

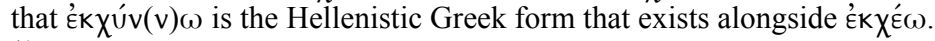

41 Matthew makes the connection between Jeremiah and Jesus more explicit. The Matthean narrator includes the woes against the religious leaders pronounced by Jesus (Matt. 23). The climax of these judgement oracles is the accusation that they have killed and crucified the prophets, wise men and scribes God has sent. He warns them that 'upon you will come all the righteous blood that has been shed ( $\pi \tilde{\alpha} v$ a $\tilde{i} \mu \alpha$ Síkalov ÉkXuvvó $\mu \varepsilon v O v$ ) on the earth, from the blood of righteous Abel to the blood of Zechariah, son of Berekiah, whom you murdered between the temple and the altar' (23:35). 


\section{Mark 12:2-4}

Jeremiah's prophecy also seems to exercise some influence upon the story of the tenant farmers (Mark 12:1-12) that stands midway between the temple incident and its prophesied destruction in 13:1-4. Jesus uses the vineyard ('̊ $\left.\mu \pi \varepsilon \lambda \omega^{\prime} v\right)$ as a symbol for Israel and the tenant farmers probably represent Israel's ruling elite. C. Evans demonstrates ${ }^{42}$ clearly the many linkages between this story and Isaiah's song of the vineyard (Isa. 5:1-7). ${ }^{43} \mathrm{He}$ also notes that Jeremiah uses the same symbolism for Israel. ${ }^{44}$

Two passages in Jeremiah are most significant. At 2:21, as we have already seen, God has 'planted' a fruit-bearing vine of good stock, but it changes and becomes a 'strange vine', no longer true to its breeding. He describes Israel as 'my vine', but its rebellious activities demonstrated in its idolatrous worship have corrupted it. ${ }^{45}$ The other passage, a prophetic lament, is 12:10:

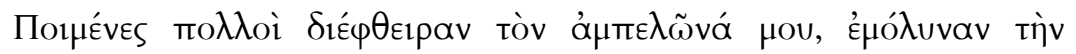

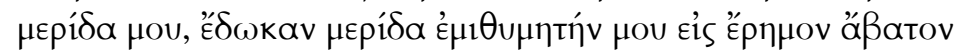

Many shepherds have destroyed my vineyard, they have defiled my portion, they rendered my desired portion an untrodden wilderness

Earlier in this oracle God has warned that he will 'forsake my house, abandon my inheritance; I will give the one I love into the hands of her enemies' (v. 7). The result is that Israel will become a wasteland as 'shepherds' devastate the land. ${ }^{46}$

The strongest connection with Jeremiah in Mark's parable occurs in vv. 2-4. Within the Markan account the various messengers sent

42 C. Evans, Mark 8:27-16:20, 215-31.

43 Evans (Mark 8:27-16:20,230) concludes that 'the parable is consistent with the prophetic indictment of 11:17...and functions as an implicit answer to the ruling priests' question in 11:28. It is also consistent with Jesus' prophecy of the temple's destruction (13:2) and the later accusation that he had threatened the temple (14:58; cf. 15:29).'

44 Ibid., 231.

45 Jer. 6:9 compares the remnant of Israel to the last grapes on the vine to be gathered.

46 The identity of these shepherds is not exactly clear. Many who comment on the Hebrew text propose that the shepherds are the foreign enemies of Israel who have 'devastated the land'. However, the Greek translation is not quite so specific. In many contexts the shepherds are in fact the leaders of Israel $(2: 8-9 ; 3: 15 ; 10: 21 ; 23: 1-2,4$; $25: 34-36$ ). Perhaps only in $6: 3$ and maybe $12: 10$ would the shepherds represent hostile enemy forces. 28:23 and 29:19 use 'shepherd' of any ruler in the surrounding nations that might oppose the actions of God. C. Evans, Mark 8:27-16:20, 232 takes the reference to shepherds in Jer. 12:10 as a reference to Jewish leaders. 


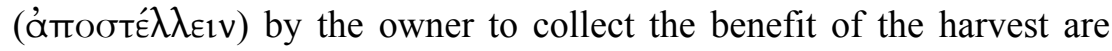
consistently designated as $\delta$ oũ ${ }_{0} 1(12: 2,4)$. These terms in Jeremiah describe the prophet's call from God. He defends himself against accusations of misrepresenting God by affirming kúpıos åm $\pi \dot{\varepsilon} \sigma \tau \varepsilon 1 \lambda \varepsilon \dot{\varepsilon} \mu \varepsilon$

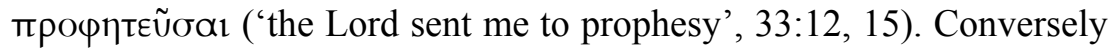
he criticizes other self-proclaimed prophets as those God says oúk

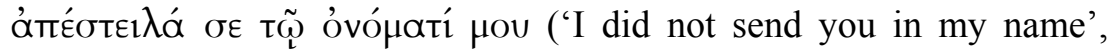
$36: 9,25)$. He himself gets accused of this same charge (50:2). In 7:25

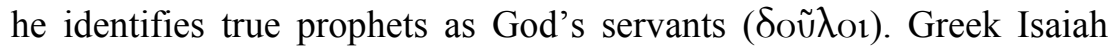
does not use this terminology (i.e. sending my servants the prophets).

It is in Jeremiah 7:25, however, that we discern the closest parallels with Mark 12:5. The Septuagint renders this verse:

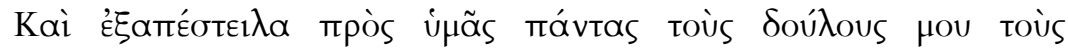

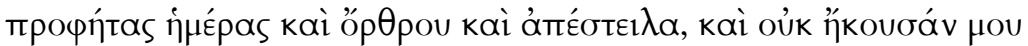
I have also sent out all my slaves the prophets to you by day and early in the morning I also sent and they did not obey me

In contrast to God's intent the result is that the people made their necks stiff (7:26). The narrator of Mark describes the action of the vineyard owner in similar terms:

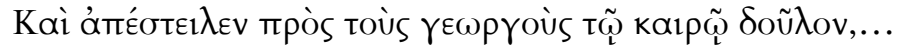

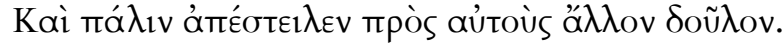

'At harvest time he sent a servant to the tenants' (v. 2)

'Then he sent another servant to them'(v. 4)

The mistreatment of the owner's servants in Jesus' story parallels the refusal by Israel's elite in Jeremiah's day to accept him as God's prophetic servant and the resultant mistreatment he experienced. ${ }^{47}$

Jesus ends his story by quoting from Psalm 118:22-23 (Mark 12:1011). The theme of rejection that it expresses is also found in Jeremiah 8:9. The prophet complains that the wise have been made ashamed

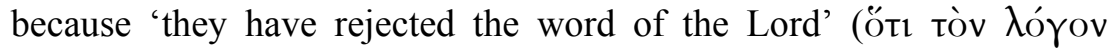

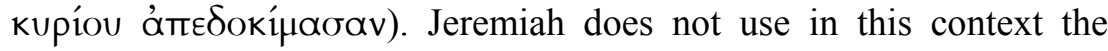
metaphor of the rejected stone. However, apart from Psalm 118:22-23, this is one of the few contexts in the Greek Old Testament where this verb occurs. ${ }^{48}$

47 Jer. 26:20-23. cf. 2 Chr. 24:20-22.

48 Jeremiah also uses this verb to describe God's rejection of Israel $(7: 29 ; 14: 19)$. This verb occurs most frequently in the LXX of Jeremiah. 
It is true that we have no specific quotation or even explicit allusion from Jeremiah in the tenant farmer story that compares to the parallels with Isaiah 5:1-7. However, the Isaiah connections come primarily at the beginning and end of the story (Mark 12:1-2 has allusions to Isa. 5:1-2; Mark 12:9 has parallels with Isa. 5:5-6). ${ }^{49}$ Of course, the vineyard symbolism, the desire of the owner to benefit from his vineyard, and his disappointment at the lack of fruit are structures that invite comparison. However, the aspect of sending servants at harvest time and the mistreatment motif are not part of Isaiah's vineyard song. It is specifically these elements that are paralleled in Jeremiah's prophecies and especially in the context of Jeremiah $7 .^{50}$ It may well be that in the tradition Mark received or that as he wrote this parable into the story intentional reference was made to the vineyard analogies both in Isaiah and Jeremiah.

\section{Mark 13}

According to Mark 13:1-2 Jesus prophesied to four of his own

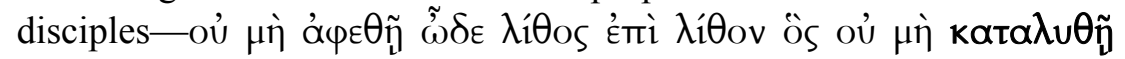
('not one stone here will be left on another; everyone will be thrown down'). The accusations ${ }^{51}$ levelled against Jesus in his trial and during his crucifixion reflect this same terminology.

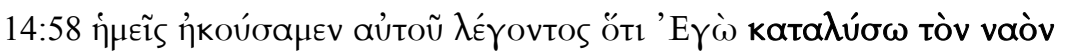

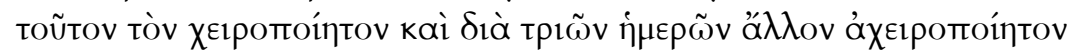

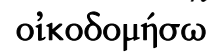

'We heard him say, "I will destroy this manmade temple and in three days will build another not made by man."

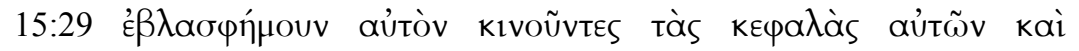

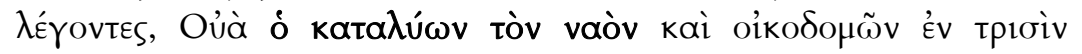

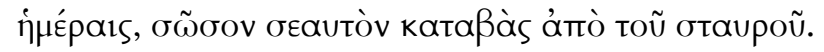

'[They] hurled insults at him, shaking their heads and saying, "So! You who are going to destroy the temple and build it in three days, come down from the cross and save yourself.",

49 C. Evans, Mark 8:27-16:20, 225, lays out the comparison with Isaiah's text.

50 C. Evans, Mark 8:27-16:20, 234, draws attention to 2 Chr. 36:15-16, but the

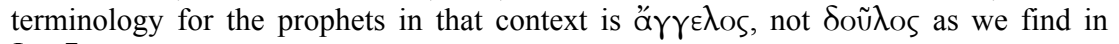
Jer. 7.

51 In the first case the narrator characterized the speakers as giving 'false testimony'. In the second instance their accusation was defined as insulting or slanderous. 
The common thread through all of these statements is the verb к $\alpha \alpha \lambda \dot{u} \omega$ and this gives credence to the accusations made by Jesus' opponents that Jesus also promised to rebuild the temple, but without human aid. ${ }^{52}$ Precisely what Jesus' role is in this destruction and rebuilding is unstated..$^{53}$ In Jeremiah's prophecy God's core message had to do with the divine destruction and rebuilding of nations and kingdoms: 'Behold, today I have appointed you over nations and over kingdoms to uproot and to pull down and to destroy and to rebuild and to plant' (Jer. 1:10). ${ }^{54}$ The emphases upon destruction and rebuilding resonate with Jesus' words about the temple in Mark's narrative.

In Jeremiah 7:4 the prophet repeated the Judaeans' mantra vaòs kúpiou, that reflected their confidence in the presence of the temple. Jeremiah warned them that God will do to this vaós what he did previously to his sanctuary at Shiloh, because of wickedness. God will

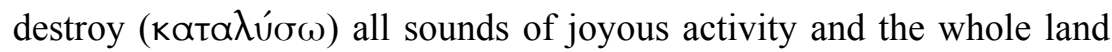
will be desolate $(7: 34 ; 16: 9)$. But Jeremiah also prophesied God's

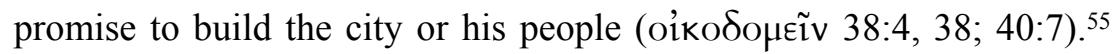
What is of significance in this terminology is that Jesus in Mark's narrative normally does not use vaós to describe the temple ${ }^{56}$ and this is the same for Jeremiah, but this is precisely the term found in both accusations reported against Jesus in Mark, and only in Jeremiah 7:4

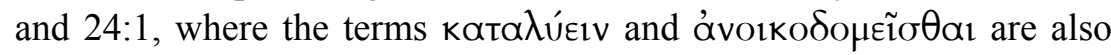

52 The narrative in John 2:19 places a similar statement in the context of a temple cleansing and explains it as a reference to Jesus' death and resurrection.

53 E. P. Sanders, Jesus and Judaism, 75 says that Jesus intended 'to indicate that the end was at hand and that the temple would be destroyed, so that the new and perfect temple might arise'. Josephus (B.J. 6.5.3. §300-309) records the hostility against Jesus, son of Ananias. When he prophesied the destruction of the temple, he was arrested and beaten. He was killed when struck by a stone during one of his prophesying sessions. C. Evans, Mark 8:27-16:20, 485-96 has an excursus on this event and its implications for the arrest, trial and execution of Jesus Christ.

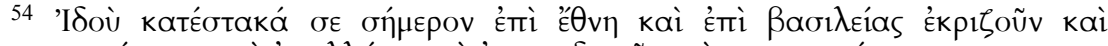

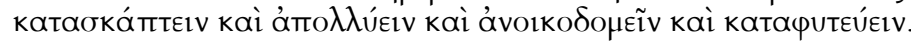

55 In the prophecy that was formed around the potter and clay illustration God promised that if a nation or king turned from its evil, then God will 'repent concerning

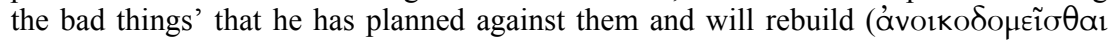
18:9) and plant that nation or king. Similarly in the prophecy built upon the good figs and bad figs (24), the people represented by the good figs will be restored and rebuilt

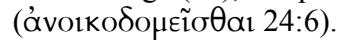

56 The only other context in Mark's Gospel where vaós occurs is 15:38, when the veil of the temple (voós) was ripped in two. Perhaps the Markan narrator expects his reader or listener to connect this note about the temple veil's destruction to Jesus' prophecies about the temple. 
found. I would suggest that this is a significant connection with Jeremiah's material.

The Markan narrator, in addition to the Daniel references, also seems to have included specific themes and terminology in Mark 13 that parallel Jeremiah's oracles, particularly those that concern the temple and its destruction. The Danielic references in this discourse are well known. In its list of quotations and allusions to the Old Testament materials, Nestle-Aland 27 makes no mention of Jeremiah material in Mark 13. Nestle and Aland list a 'parallel reference' in the margin at Mark 13:2 to Jeremiah 7:14. In their indices C. Evans and BeasleyMurray $^{57}$ note many references to Jeremiah material in relation to Mark 13, indicating that in their view, Jeremiah's material has significance for the Markan narrator in this discourse. We have already discussed how Jesus' primary oracle in Mark 13:2 parallels Jeremiah's prophecy of the destruction of the temple.

We discover two kinds of references to Jeremiah material in Mark 13. One type of reference includes the kinds of prophetic speech and ideas that Jeremiah shares with other Old Testament prophets. For example, in Mark 13:5-13 Jesus warns his followers not to be deceived $(\mu \grave{\eta} . . . \pi \lambda \alpha v \dot{\sigma} \sigma \eta$, vv. 5-6) when they hear of 'wars and rumours of wars...earthquakes... and famines’ (Mark 13:7-8). Jeremiah similarly prophesied that God will bring earthquake $(10: 22 ; 23: 19 ; 36: 3)$ and famine $(11: 22 ; 14: 2,16 ; 18: 21 ; 21: 7 ; 24: 10 ; 39: 24)$. Babylonian armies will attack and destroy Jerusalem (7). Jesus warns his followers that

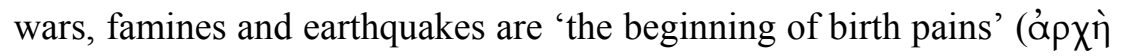

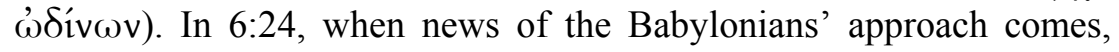
Jeremiah compares the Judaean's response to the pains of birth: 'anguish took hold of us, pains as of one giving birth'. ${ }^{58}$ What is different in the case of Jesus is that he is not specifically defining such events as God's judgement against any particular group, as Jeremiah did, but indicates that these kinds of events will characterize history and are harbingers of what will occur at the end (just the beginning of birth pains).

This leads us to consider the second type of reference - more specific verbal allusions that may reflect a particular element in

57 C. Evans, Mark 8:27-16:20, 572-73; G. Beasley-Murray, Jesus and the Last Days. The Interpretation of the Olivet Discourse (Peabody, MA: Hendrickson, 1993): 500501.

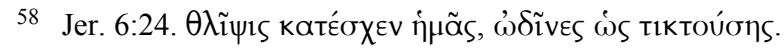


Jeremiah's oracles. One notable element in Greek Jeremiah is its trans-

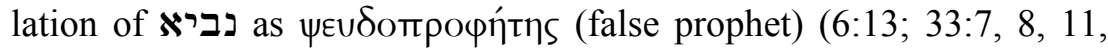
$16 ; 34: 7 ; 35: 1 ; 36: 1,8) .{ }^{59}$ Of course, the Hebrew term means 'prophet' and only context can determine whether the speaker intends to identify a true or false prophet. The Greek translator of Jeremiah removed any doubt for his audience. Jesus warns his disciples about future

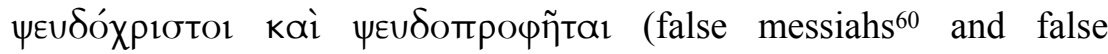
prophets) who will arise and 'deceive the elect - if that were possible' (Mark 13:22). Jeremiah fears the effect of such people because they speak and act 'falsely' ( $\psi \in \cup \delta \tilde{n}$ 6:13; 34:7-8) and clamour for Jeremiah's death (33:7-11). Of course, this term achieves greater currency within Jewish literature as a result of the usage in Greek Jeremiah and so we cannot assert that Jesus alludes to Jeremiah in any specific sense, but the deception by false prophets is an important ideological parallel and we do have the lexical similarity.

One other potential allusion comes in Mark 13:14 when Jesus describes the 'abomination that causes desolation' (tò $\beta \delta$ '́ $\lambda u \gamma \mu \alpha$ tñ

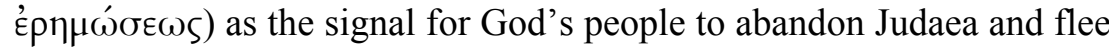
into the mountains.

In Greek Jeremiah we find the concept of 'detestable (tò $\beta \delta \varepsilon \lambda$ ú$\mu \alpha \tau \alpha)$ things coming from his [Israel's] mouth' (4:1) linked with the warning about the enemy from the north, aroused by God, that will come in order to destroy the land (eis épn $\mu \omega \sigma \mathrm{iv})$ (4:7). Again in 7:30 God criticizes the Judaeans for 'arraying abominations (tò $\beta \delta \varepsilon \lambda u_{\text {Y }} \mu \alpha \tau \alpha$, i.e. idols) in the house where my name is called on it, to defile it'. God warns that 'all the land shall become a desolation (Eis '́ṕn $\mu \omega \sigma \mathrm{ov})^{\prime}$ (7:34) as a consequence. ${ }^{61}$ As well, we find the same linkage in 51(44):22:

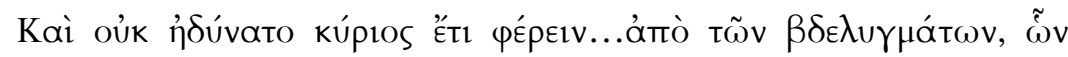

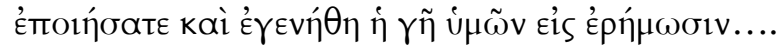

59 There is only one other usage in Zech. 13:2. Jeremiah often speaks of those who prophesy falsely.

60 This is the first occurrence of this word in surviving Greek literature. Presumably it is formed on the analogy of $\psi \varepsilon v \delta о \pi р о \varphi \tilde{\eta} \tau \alpha$.

61 Jer. 7:10 also mentions the Judaeans' abominations and they are related to their failure to keep the commandments. 
And the Lord could no longer bear up...before the abominations that you committed and your land became a desolation $\left({ }^{62}\right)$

For Jeremiah it is the 'abominations' of the Judaeans, primarily their idolatry, but also their failure to obey God's commands that caused God to destroy Jerusalem and the temple. The agent of judgement and desolation is a foreign power, i.e. the Babylonians, but they are not the source of the abominations.

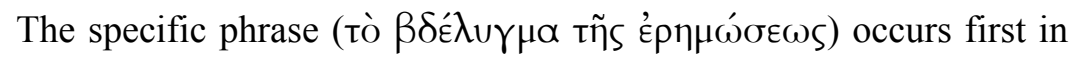
Daniel's material (Dan. 9:27; 11:31; 12:1). The prophet was studying Jeremiah's prophecy about the 'desolation of Jerusalem'. ${ }^{63}$ Jeremiah's language probably influenced the choice of terminology in Daniel. ${ }^{64}$ However, to determine what the Daniel narrator meant by this phrase is more problematic. The sense in Greek Daniel is that this 'abomination' arises because of the actions of a foreign king. Desolation ensues within Israel because its religious fabric and rituals are desecrated. However, this foreign king gains the support of many within Israel, those who will violate the covenant (11:32). So Daniel's application of the term 'abominations' is quite different from Jeremiah's in the sense that while both seem to refer to idolatrous practices within the temple precinct, in Jeremiah's prophecies it is the Judaeans who are responsible, while in Daniel's material it seems to be an external, foreign king who is responsible for this desecration, even though many in Israel may also acquiesce. As well the desolation that results is somewhat different. In Jeremiah's case God uses a foreign power to bring judgement against his own people for their idolatry. However, in Daniel the desolation seems rather to be the persecution that comes against those who remain loyal to the covenant and part of this persecution includes attacks upon the temple.

When we come then to Jesus' use of the phrase $\beta \delta \varepsilon \lambda_{u} \gamma \mu \alpha$ iñ

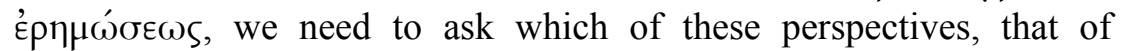

62 Jer. 51(44):6 warns the Jews who fled for refuge to Egypt that if they continue to practice idolatry, God would destroy them as he destroyed Jerusalem and the temple.

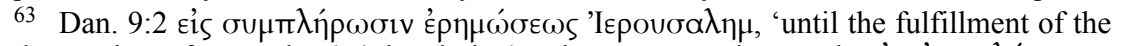

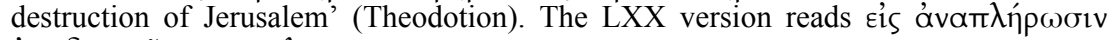

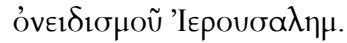

64 C. Evans, Mark 8:27-16:20, 317-18 says that 'Daniel's language may have been inspired by Jer. 44:22 (LXX 51:22): "The Lord could no longer bear your evil doings and the abominations [LXX: $\beta \delta \varepsilon \lambda \cup \gamma \mu$ ó $\tau \omega v]$ which you committed; therefore your

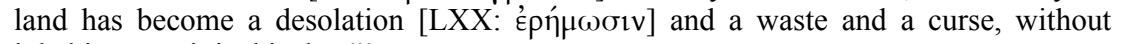
inhabitant, as it is this day.", 
Jeremiah or Daniel, formed the primary background. In the Markan narrative Jesus does not specifically refer to Daniel as the source, but the expression 'Let the reader understand' certainly could point to an Old Testament source or sources that need to be interpreted carefully in the light of Jesus' own claims. ${ }^{65}$ Mark may deliberately have used similar phraseology in order to demonstrate the inter-connectedness between Jesus' actions and Israel's history, but may apply this phrase in a distinctive manner. ${ }^{66}$

We are left to discern whether we should understand Jesus' use of this phrase only in the light of Daniel's usage or whether Mark also intended Jeremiah's prophecy to serve as a significant context for understanding ${ }^{67}$. When Jesus warns his disciples to flee Jerusalem "when they see the abomination that causes desolation standing where he does not belong', what is the abomination? Is it something that Israel has done in disloyalty to God's covenant, as is the case in Jeremiah, or is it something perpetrated on Israel by a foreign agent? Is the desolation that results God's judgement upon Israel or the persecution of the righteous remnant by some foreign power? ${ }^{68} \mathrm{We}$ cannot solve this problem in this paper. What I hope is clear is that we should consider Jeremiah's prior usage of this terminology in our understanding of Jesus' words along with Daniel's material. Even though Matthew's narrative explicitly notes that this phrase comes from Daniel, this does not require us only to interpret Mark's narrative in the light of Daniel's text.

By examining contexts in the Markan narrative where potential inter-textual linkages with Jeremiah's prophecy occur I have sought to demonstrate the potential contribution of Jeremiah's material to our understanding of Mark's purpose. His use of Jeremiah's material

65 Matthew's narrative is quite explicit, mentioning Daniel as the source of this phrase (Matt. 24:15). Luke, similar to Mark, does not specify any source. In fact he does not

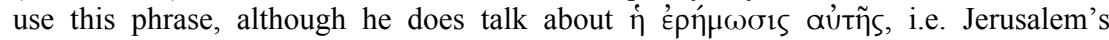
desolation at the hand of foreign armies (Luke 21:20).

66 L. Perkins, "Let the Reader Understand": A Contextual Interpretation of Mark 13:14', BBR 16 (2006): 95-104 argues that at the story level 'Jesus is directing any among his current disciples and those beyond this circle who read the Daniel materials related to the "abomination that causes desolation" to read them in the light of his interpretation and thus to read them with understanding.'

67 The phrase is also used in 1 Macc. 1:54-56 where it describes the actions of Antiochus Epiphanes to desecrate the Jerusalem temple.

68 Various surveys of the interpretation of this phrase are available in the literature. Desmond Ford, The Abomination of Desolation in Biblical Eschatology (Washington, DC: University Press of America, 1982). 
occurs almost exclusively in contexts where Jesus experienced or discussed opposition. The theme of obduracy and its expression in the temple cleansing incident, in the parable of the tenant farmers, and in the prophecy about the destruction of Jerusalem and the temple, seems to provide the thread that links Mark's portrayal of Jesus with Jeremiah's message. While Jesus has many positive interactions with Jewish people and experiences some amazing responses, there is rejection and outright antagonism expressed primarily by the Jewish religious leaders in the Markan structure. It is the latter stream of experiences that resonates with Jeremiah's message and prophetic vocation. The Markan author discerned in Jeremiah's experience a context in Israel's history that paralleled that of Jesus. He worked quotations, allusions and themes from Jeremiah into his narrative, using this prior narrative substructure to help discerning readers or listeners understand the dynamics unfolding in the Jewish response to Jesus and its implications. 